\title{
Framing Grass: The Reception of Die Blechtrommel in Flanders
}

\author{
Elke Brems
}

\begin{abstract}
Der vorliegende Beitrag erörtert die Rezeption der Blechtrommel in Flandern unter Benutzung von Mona Bakers Konzept des narrativen, framing. Im Mittelpunkt steht die Frage, wie flämische Rezensionen dem Roman bestimmten Deutungsrahmen - frames - zugeordnet haben. Der Beitrag unterscheidet fünf solche in Rezensionen auftauchende Deutungsrahmen und geht auf einige der dabei verwendeten Verfahren (,framing devices') etwas näher ein. Der erste Deutungsrahmen stellt den Roman als Teil des Kanons dar und betont seinen raschen Aufstieg zum Klassikerstatus. Der zweite Rahmen verweist auf die Botschaft, die Kritiker in dem Roman ausgemacht haben, wobei drei Aspekte in den Vordergrund treten: Deutschland, Oskar und die moralischen Absichten des Romans. Ein dritter Deutungsrahmen geht von den formalen Neuerungen aus, mit denen Die Blechtrommel bestehende Gattungskonventionen durchbricht. Die Aufnahme bestehender kritischer Rezeption in die eigene Rezension ergibt einen vierten Deutungsrahmen, und die Verbindung zwischen Roman und Autor schließlich bildet einen fünften Rahmen, in dem Grass als vom eigenen Meisterwerk geprägte Persönlichkeit des öffentlichen Lebens herausgestellt wird.
\end{abstract}

\section{A Flemish Blechtrommel}

In her book Translation and Conflict. A Narrative Account, Mona Baker takes a narrative point of view on reality. Her basic assumption is that we experience the world as a collection of narratives. But those narratives are not fixed; they are dynamic and exist through telling and retelling. And they also travel; they cross borders, geographically, linguistically and culturally. "Every time a version of the narrative is retold or translated into another language, it is injected with elements from other, broader narratives circulating within the new setting or from the personal narratives of the retellers." ${ }^{1}$ This paper will attempt to

$1 \quad$ Baker (2006) 22.

(C) ELKE BREMS, 2016 | DOI 10.1163/9789004291898_009

This is an open access chapter distributed under the terms of the CC-BY-NC License. 
map the retelling of the narrative Die Blechtrommel in Flanders, the Dutchspeaking part of Belgium, using several of Mona Baker's concepts.

Before we look at the reception of Grass's novel in Flanders, it is important to emphasise the following point. Flanders shares its language with the Netherlands, its northern neighbour. Whether both regions also share the same culture has been the subject of long and heated debate since the beginning of the nineteenth century. For Flanders to emancipate its cultural identity from the francophone part of Belgium, it often had to rely on the Netherlands for support. But, paradoxically, as Flanders gained more and more self-confidence during the second half of the twentieth century, Flemings felt the need to present themselves as autonomous from the Dutch. The relation between Flanders and the Netherlands is of course much more complex than that, but the general belief is nevertheless that Flemish culture and Dutch culture have increasingly grown apart since the Second World War, in spite of sharing the same language. That is why any examination of the Flemish reception of Die Blechtrommel carries a few pitfalls. Both Dutch translations of the novel were for instance made by Dutch translators and published by a Dutch publishing house. ${ }^{2}$ There are far more publishing houses in the Netherlands than in Flanders, and the literary translation industry also has a much greater output. This paper will therefore not address the translations themselves. The reception of those translations extended to both Flemish and Dutch newspapers, journals, schoolbooks, libraries and so on. I will only discuss the Flemish press and institutions.

Reine Meylaerts has argued that Belgium has two minority cultures: ${ }^{3}$ a francophone and a Dutch-speaking one, both dominated by larger and older neighbouring cultures that speak the same languages - France and the Netherlands respectively. Die Blechtrommel was introduced in the francophone part of Belgium through translations made and published in France. The reception of Die Blechtrommel in francophone Belgium was consequently very different, although there are of course likely to be parallels with the reception in both France and the Netherlands.

2 De blikken trommel, Amsterdam, Meulenhoff, 1964 (translation Koos Schuur). De blikken trom, Amsterdam, Meulenhoff, 2009 (translation Jan Gielkens).

3 Meylaerts (2008) 29 . 


\section{Die Blechtrommel as Narrative}

Literature, according to Mona Baker, can be considered a type of public narrative. Public narratives are "stories elaborated by and circulating among social and institutional formations larger than the individual, such as the family, religious or educational institutions, the media, and the nation. (...) literature of course constitutes one of the most powerful institutions for disseminating public narratives in any society." 4 She distinguishes between four kinds of narratives, based on a typology by Margaret Somers and Gloria Gibson. Ontological narratives are personal stories, but some literary text types are also believed to have this ontological dimension, for instance, diaries (think of Anne Frank), letters or autobiographies. Yet they would of course also heavily depend on public narratives, especially when edited, published and so on. Conceptual narratives, in Baker's view, are the discourses used by disciplines such as the narrative of a paper in a collection on the reception of Die Blechtrommel. Books like Die Blechtrommel, but also for instance autobiographies, depend on and make use of the conventions of conceptual narratives, mainly by applying or challenging generic conventions. The last type of narrative Mona Baker describes is rather vague and broad. These meta-narratives are the narratives in which we are embedded "as contemporary actors in history." ${ }^{5}$ Baker mentions the 'War on Terror' as an example.

When looking at Die Blechtrommel from this perspective, we can consequently confirm that it shows characteristics of all four types of narrative: it contains autobiographical elements from Grass's own life (ontological narrative); it tells the story of a family, a nation, an era (public narrative); it is explicitly conceived as a literary text (conceptual narrative); and it relies on meta-narratives like liberalism and national-socialism. However, I am not so much concerned with the narrative of Die Blechtrommel itself, but with the narratives about Die Blechtrommel instead - the way the book has been and is still being retold in Flanders.

In Baker's view, any retelling of a story involves framing, which is "an active strategy that implies agency and by means of which we consciously participate in the construction of reality." ${ }^{6}$ In the following chapters, I will look at how Die Blechtrommel has been framed in Flanders. Die Blechtrommel was framed by reviews, by translations, by being cited in schoolbooks, by being purchased by libraries, by being read by readers and by being adapted into a movie (subtitled

4 Baker (2006) 33 .

5 Baker (2006) 44, quoting Somers.

6 Baker (2006) 106. 
in Dutch). Generally speaking, one could argue that the first appearance of the book in 1959 and the first translation in 1964 did not cause waves in the Flemish press. Neither did the second translation in 2009. This does not mean however that the novel is not well known in Flanders. There were paradoxically only a few direct reviews, but there are many indications that the novel and its author are very well known and considered to take an important place in contemporary literature. I found a similar pattern in an article I wrote on the reception of Charles Dickens in Flanders, with not many reviews of his novels, but a general acceptance of Dickens as a famous and important writer. ${ }^{7}$ In Dickens's case, this led to statements such as "it is not necessary to talk about his novels," or "there is no need to introduce Dickens here." In the case of Grass too, it seems that he achieved literary fame very early on in his career and that Die Blechtrommel was considered to be generally known, even though it was not very frequently reviewed. There were a few events that sparked special interest in Grass and his novel in the Flemish press: the 1979 release of the film (and every time it was subsequently shown on television or in cinemas), his 7oth birthday in 1997, his winning the Nobel Prize in 1999, his confession in 2006 and political statements he made over the years.

Die Blechtrommel and Grass were framed on all those occasions. I will discuss those frames as narratives used by agents to retell Die Blechtrommel. In what follows I will mention the five most important frames used, with no pretension of an exhaustive discussion of the frames or the reception documents. I will also point to some of the framing devices used.

\section{Frame 1: The Literary Canon}

When the novel first appeared in 1959, Grass was of course still a little-known author. I only found one Flemish 1959 review and four others written between 1960 and 1962 (the first Dutch translation appeared in 1964). In the first review by Catholic priest Henrik Hartwijk (a Netherlander who lived in Brussels) in the Catholic newspaper De Nieuwe Gids, Grass and Die Blechtrommel were framed by means of embedding. "The author owes this success in the first place to his extraordinary imaginative power and his lively way of telling; the first reminding us of Balzac and the second of Dickens. Some have even compared Grass to Rabelais." Hartwijk immediately enters Grass in the frame

7 Brems (2010). 
of some of the greatest names in European literature. ${ }^{8}$ Further down in his review, he also mentions Thomas Mann, another German writer: "Ever since Die Buddenbrooks by Thomas Mann, no debut in German literature has shown such remarkable talent as Die Blechtrommel." Mona Baker would describe this technique as 'framing by labelling'. This labelling puts Grass high up in the ranks of European literature (not just contemporary literature but that as far back as the 16th century) and also makes him a milestone in German literature.

This could also be considered 'temporal and spatial framing'; his timeframe is then not just contemporary but instead goes centuries back, and his space frame is not just Germany, but Europe. Another early review (1961) brings Die Blechtrommel into the tradition of Gargantua and Simplicissimus, but also into that of Joyce. ${ }^{10}$ As Grass's fame grows, the embedding technique, aimed at giving Grass's book a literary context, turns into a different, almost reverse kind of framing by labelling in which Grass's book increasingly becomes a mention, a point of reference for other books. This obviously means that Die Blechtrommel has become part of the canon and that it can be referred to in other book reviews to increase their value. In Flanders, it seems that Hugo Claus' novel Het Verdriet van België [The Sorrow of Belgium, 1983] was the one most often compared to Grass's Die Blechtrommel. One Flemish critic even quoted German critics who mentioned Grass in their review of Claus: "German literary critics often compared this novel to Die Blechtrommel by Günter Grass, with Louis Seynaeve often seen as a brother of the frenetic little drummer Oskar from Danzig."11 German literary criticism is in other words used as an authoritative source to increase Claus's value. But when foreign literature is reviewed in the Flemish press, Grass is also sometimes mentioned. A good example can be found in Jonathan Safran Foer's Extremely Loud \& Incredibly Close (2005), in which the child protagonist is also called Oskar and has German ancestors. ${ }^{12}$

Another kind of embedding appears only later on in Grass's career, when his oeuvre has grown. We then see how critics compare Grass's other work with

$8 \quad$ Hartwijk (1959). "Dat succes dankt de schrijver wel eerst en vooral aan zijn buitengewone verbeeldingskracht en levendige vertellingswijze, waarvan de eerste aan die van Dickens, de tweede aan die van Balzac doet denken. Sommigen hebben Grass zelfs al met Rabelais vergeleken." All English translations in the text by E.B.

“(N)a 'Die Buddenbrooks' van Thomas Mann (heeft) geen enkele eersteling in de Duitse letteren zo'n ongemeen groot talent (...) geopenbaard als 'De blikken trom."”

10 Pesch (1961).

11 "De Duitse kritiek vergeleek de roman geregeld met Die Blechtrommel van Günter Grass, waarbij Louis Seynaeve werd beschouwd als een broer van het frenetieke trommelaartje Oskar uit Danzig."

E.g. De Decker (2005); Verplancke (2005). 
Die Blechtrommel. Die Blechtrommel is always believed to be Grass's greatest achievement and it is often said he never reached the same level again. ${ }^{13}$

There are other ways of using the frame of the literary canon to receive Die Blechtrommel. Public libraries for instance represent institutions that function as canon-building stocks, especially where foreign and non-contemporary literature is concerned. In a survey I conducted among 98 public libraries in the province of Flemish Brabant, I found that 31 of them, or a third of them, had a copy of Die Blechtrommel on their shelves. However, it is worth pointing out that only four of those had a copy of the most recent translation, which might indicate that it is not a book they want to invest in. It would take more research - and a comparison with other 'classic novels' in particular - to do justice to these numbers.

Schoolbooks also offer an important means of canonisation. I examined 22 textbooks for German published in the last two decades and used in Flanders in that same period. ${ }^{14}$ Only in one of them, Kontakt, did I find an excerpt of Die Blechtrommel. This means that German-learners are not introduced to Die Blechtrommel, but it does not necessarily mean that the novel is not considered part of the German canon. It is definitely not considered a fitting reading assignment for German learners, but that may also be because of the difficulty of the text. Schoolbooks are moreover becoming increasingly oriented toward a communicative approach, so that literature does not constitute an important part of the curriculum. If we look at scholieren.com, a Dutchlanguage website on which students from the Netherlands and Flanders post and share their book reviews, we notice that there are only three reviews of Die Blechtrommel, compared to for instance 12 reviews for Böll's Katharina Blum, which is also rated much higher. Of course, here too, more research would be needed to better situate Die Blechtrommel against the context of other novels.

One of the main canon-indicators are the media lists of books one should read to have (or pretend to have) cultural standing. Newspapers sometimes use this format to write about non-contemporary books. In 1999, the newspaper $D e$ Morgen for instance published a weekly column about 'the most remarkable books' published between 1945 and 1999. Die Blechtrommel was one of them..$^{15}$ In 2006, the newspaper De Standaard published a column called 'Blufboek'

13 Durnez (1999). "Hij heeft het niveau van zijn debuutroman De blikken trommel nooit meer gehaald."

14 Em., .de, Dimensionen, eurolingua, Angenehm, Fix und fertig, Geni@l, Klub 20oo, Kontakt, Los geht's, Mach's gut, Mittelpunkt, Sowieso, Sichtwechsel, Studio d, Die Suche, Tangram, Themen, Umlaut, Variant, Wir, Zeppelin.

Bultinck (1999). 
(10o highlights of modern literature, "for your bookshelves, at receptions or among friends"). ${ }^{16}$ Again, Die Blechtrommel was one of them.

But also outside the context of such lists, Grass's Die Blechtrommel is often referred to as one of the great novels of the 2oth century, for instance by describing it as a 'modern classic. ${ }^{17}$ We find many unsubstantiated comments such as: "Without exaggerating, Die Blechtrommel can be called the most important German-speaking novel of the second half of the 2oth century."18 This consecration of the novel already began in the earliest reviews. In the Jesuit cultural journal Streven, a critic for instance admitted in 1961 he would not call the book a masterpiece, or even a work of art, but "whoever wants to understand the contemporary novel cannot overlook this book."19 In De Periscoop too, in 1962, a reviewer claimed the novel "had no equal in contemporary literature."20

In an interview on Belgian television in 1999 Grass himself situates his oeuvre (not just Die Blechtrommel) in the context of German-language literature (so not just German literature: "I can't see literature as national literature"). ${ }^{21}$ Other critics stress the importance of Die Blechtrommel to German literature by arguing that Grass succeeded in making "a German book (...) loved throughout the world, thereby liberating German literature from the suffocating shadow of the Second World War."22 But Die Blechtrommel is also considered to be relevant to a broader readership than just Germans or German speakers. "In this monumental European novel, Grass challenges the great forgetting of the Second World War." ${ }^{23}$ This not only represents a spatial framing, but also a 'repositioning of the participants'. The novel now not only appeals to 'them' but also to 'us'; it is not just 'their' novel but 'ours'. This brings us to a second frame used to retell Die Blechtrommel - a moral frame. In this frame, the novel is not only read and discussed as a literary masterpiece, but also as the bearer of a message.

16 Derycke (2006). "Honderd hoogtepunten uit de moderne literatuur. Voor in uw boekenkast, op recepties en bij vrienden."

17 Verhoeven (2006).

18 Durnez (1999).

19 De Wachter (1961). "Maar wie de hedendaagse roman wil begrijpen, kan aan dit werk niet voorbijgaan."

$20 \quad$ E.P. (1962). "zijns gelijke niet heeft in de hedendaagse literatuur."

21 <http://www.cobra.be/cm/cobra/cobra-mediaplayer/boek/1.1268692> (minute 11).

22 Moonen (1997). "Een Duits boek, De blikken trommel, in de wereld geliefd te maken en zo de Duitse literatuur uit de verstikkende schaduw van de Tweede Wereldoorlog te halen."

$23 \mathrm{kgv}(2008)$. "Grass rekent in deze grandioze Europese roman af met het grote vergeten van de Tweede Wereldoorlog." 


\section{Frame 2: The Message}

In her chapter on the assessment of narratives, Mona Baker argues that we largely assess narratives on their coherence and fidelity. An important part of the perception of coherence is tied to how the story relates to the other stories we are familiar with. In the previous paragraph, we already discussed how the relation between Die Blechtrommel and other literary stories was assessed, but those are not the only stories Die Blechtrommel is related to. It is also assessed in the way it relates to stories of a social, political, historical or ideological nature. The most obvious way in which this happens is when the theme of Die Blechtrommel is discussed. Often, when the theme is addressed, reviewers use the framing device Baker calls 'selective appropriation of textual material'; they neglect most of the novel and focus on a few scenes or characters. Germany or issues pertaining to Germany are most often considered to be the theme of this book. In the earliest review I found, Henrik Hartwijk writes: "The real protagonist is Germany."24 Elsewhere, it is called "the first great work of fiction about Nazism," ${ }^{25}$ a "book about the rise of national-socialism," ${ }^{26}$ or it is claimed that "Die Blechtrommel (...) condemned the schizophrenia of postwar Germany."27

A term that returns in later reviews is Vergangenheitsbewältigung, for which no Dutch alternative seems to exist. By using it in its untranslated form, the reviewer places the novel in a strictly German context. Aside from interpretations of the book as a comment on German history, a second thematic cluster prominent in the reviews concerns the character of Oskar. When this theme comes up, reviewers for instance paraphrase the book as "the story about the boy who didn't want to grow up." 28 A recent comment on the novel offered the following interpretation: "The Oskar Matzerath-syndrome is just that tiny bit more complex and interesting than the Peter Pan-syndrome. The first syndrome is tragic, romantic and nihilistic, a reaction to the worst of the past century, imbued with guilt, anger and despair. The second is the narcissistic pose of those who prefer to live in a sugary Disney atmosphere. Put differently, Michael Jackson does not suffer from the Oskar Matzerath-syndrome."29

24 Hartwijk (1959). "De eigenlijke hoofdfiguur is Duitsland."

25 Anon. (1998). "het eerste grote fictiewerk over het nazisme."

26 Joris (2007).“boek over de opkomst van het nationaal-socialisme.”

27 Verhoeven (2006). "laakte de schizofrenie van het naoorlogse Duitsland."

28 Pearce (2009). "het verhaal van de jongen die niet wilde groeien."

29 Theunissen (2009). "Het Oskar Matzerath-syndroom is dus net iets complexer en interessanter dan het Peter-Pansydroom. Het eerste syndroom is tragisch, romantisch en nihilistisch, een van schuld, woede en wanhoop doordrongen reactie op het ergste van de 
The two thematic clusters, both the one about Germany and the one about Oskar, are often linked to an assessment of the values, or the lack of values, in Die Blechtrommel. Consider this example linking Oskar to values: "The strength of the Oskar Matzerath character is the honesty with which he looks at himself and the world around him. In a nihilistic, amoral era he is no better than anyone else, but at least he calls things by their names." ${ }^{30}$ This moral judgment is a positive one. We know that the book's reception in Germany stirred a lot of moral outrage (see Frame 4: Critical Reception). In Flanders, however, there were comments on that outrage, but very few moral condemnations. In one of the earliest reviews in 1960, Lea Verkein for instance wrote: "Grass tells a story, he doesn't take sides, doesn't want to prove anything, defend anything, judge anything, condemn anything, he doesn't avoid any problem, draws no conclusion." ${ }^{31}$ But being a liberal, she does not seem to condemn that attitude; instead she even seems to admire him for it.

The most striking moral judgement is offered by Dr. Ludwig Pesch in a special 1961 issue on the Federal Republic of Germany in the Catholic journal West-Vlaanderen. The title of his review was "Question whether Satan is a good artist." The reviewer described the moral value of the novel in very negative terms: "the mean, savage, blasphemous, satanic and perverse on occasion prevail." ${ }^{2}$ The writer did recognise the parodic character of the novel however and interpreted Oskar as a parody of "the current type of person, of his rotten, cynical, cold, godless, Luciferian soul and his nihilistic mind." Because of the critical nature of the novel, he could see the relevance of this parody, but his main reservation concerned the absence of God. He believed this to reveal a "radical Mephistophelian perspective." So, the reviewer, writing his review in a Catholic journal (published by the Christelijk Vlaams Kunstenaarsverbond [Christian Flemish Circle of Artists], could not but condemn the book, since it

voorbije eeuw, het tweede is narcistische aanstellerij van lui die het liefst zouden leven in de zeemzoeterige sfeer van een Disney-film. Of anders gezegd: Michael Jackson lijdt niet aan het Oskar Matzerath-syndroom."

30 Theunissen (2009). "De grote kracht van de figuur Oskar Matzerath is de eerlijkheid waarmee hij naar zichzelf en de wereld rond zich kijkt. In een nihilistische, amorele tijd is hij niet beter dan de anderen, maar hij noemt de dingen ten minste bij naam."

Verkein (1960). "Grass vertelt, hij kiest geen partij, hij wil niets bewijzen, niets verdedigen, over niets oordelen, niets veroordelen, hij vermijdt geen enkel probleem, hij trekt geen enkele conclusie."

Pesch (1961). "het gemene, woeste, godslasterlijke, satanische en perverse bijwijlen overwegen", "de parodie van een huidig mensentype, van zijn bedorven, cynische, koude, goddeloze, luciferiaanse ziel en van zijn nihilistische geest", "een radicaal mefistofelisch perspectief." 
offered us no alternative, did not show us how we ought to live. However, he could not but express his admiration for the book as a radical rethinking of the novel and as a stylistic masterpiece. The formal characteristics of the book are so striking that a discussion of the content alone does not seem to do justice to the book.

\section{Frame 3: Literary Form}

Ever since the first reviews, critics have pointed to the untraditional literary form of Die Blechtrommel. Only one of the critics in my corpus thought that Grass should have paid more attention to form. In the Jesuit journal Streven, De Wachter wrote: "The technique of Grass's novel is also an epochemachende invention, and one wonders to what extent the novelist himself is a Geschöpf of his own invention, or rather whether his virtuosity is not affecting him. Because in his novel, the material is clearly of more importance than the form. We wouldn't call it a masterpiece or a work of art." ${ }^{33}$ De Wachter used German words in his review, thereby stressing the German character of the book and the writer (in the process underlining his own knowledge of German). De Wachter's ambiguous comment on the artistic quality of Die Blechtrommel, however, contrasts with the general critical reception of the novel. It seems that De Wachter was blind to the formal experiment and the formal ambition of Günter Grass.

In her paragraph on assessing narratives, Baker writes that one of the criteria we judge narratives by is 'structural coherence' or the internal consistency of a narrative. This novel clearly challenges what readers had come to see as structural coherence; it is called "a staggering sequence of clownish, absurd, grotesque, harrowing and tragic episodes." ${ }^{34}$ One instrument critics have to apply to the criterion of structural coherence is the use of generic labels (framing by labelling). This fits into a conceptual narrative. Critics for instance described this novel as an epos, an Entwicklungsroman, an allegorical novel and a picaresque novel. The multitude of labels used to frame Die Blechtrommel

33 De Wachter (1961). "De romantechniek van Grass is ook een epochemachende uitvinding, en men vraagt zich af in hoever de romancier zelf niet een Geschöpf van zijn eigen uitvinding is, m.a.w. of zijn virtuositeit hem niet te veel parten speelt. Want in zijn roman is het materiaal zichtbaar van groter belang dan de vormgeving. Een meesterwerk of een kunstwerk durven wij het niet noemen."

34 Bultinck (1999). "een duizelingwekkende opeenvolging van potsierlijke, absurde, groteske, schrijnende en tragische episodes." 
point to the novelty of its literary form. The particular label used reveals the focus of the reviewer's interpretation: calling it a picaresque novel focuses attention on the adventurous and episodic character of the novel, while the term Entwicklungsroman for instance focuses attention on Oskar. In an early interview on Belgian television in 1962, Günter Grass himself also used a conceptual narrative to talk about his novel. ${ }^{35}$ Grass calls his novel an anti-Entwicklungsroman and mentions that he chose this form because it allowed him to frequently switch between scenes and perspectives. This interview shows us that formal concerns and structural coherence were indeed very important to Grass in assessing his own narrative.

\section{Frame 4: Critical Reception}

It is striking how, in the Flemish reception, Die Blechtrommel was immediately reviewed in the context of the German reception. De Wachter begins his 1961 review in Streven by saying: "You could almost write a novel about the history of this novel," and he mentions how the novel was nominated for the Rudolf Alexander Schröder Prize awarded by the city of Bremen, but was refused by the jury for being too shocking. In a 1962 issue of De Periscoop, E.P. also began by mentioning that incident and by quoting a German review in the Darmstädter Echo. Dr. Ludwig Pesch opens his 1961 article in West-Vlaanderen as follows: "Critics have furiously shredded this book to pieces or passionately celebrated it. The desperation continues: should we be enthralled or alarmed?"36 Only the very first review in De Nieuwe Gids in 1959 showed no awareness of the controversial reception. In the later critical reception too the novel was hardly reviewed without mention being made of its controversial reception, to the extent that it seemed to be one of the most appealing qualities of the book. "There was a lot of excitement when the work was published; the book was said to be pornographic, blasphemous, obscene and nihilistic,"37 or "the official complaints were nihilism and pornography - the traditional pillories for books that tread on people's sore toes." ${ }^{38}$ Marcel Reich-Ranicki's critical 'mistake' was

35 <http://www.cobra.be/cm/cobra/cobra-mediaplayer/boek/1.1268683>.

36 "De recensenten hebben dit boek woedend stukgescheurd of geestdriftig gevierd. De radeloosheid duurt voort: moeten wij begeesterd zijn of verontrust?", "Er zou haast een roman te schrijven zijn over de geschiedenis van deze roman."

37 Durnez (1999). "De opwinding na het verschijnen van het werk was groot: het boek zou pornografisch, godslasterlijk, obsceen en nihilistisch zijn."

38 "De officiële bezwaren luidden nihilisme en pornografie - de traditionele schandpalen voor boeken die op zere tenen trappen." 
also sometimes referred to. He originally execrated the book, but published a self-critical article three years later in which he admitted to having failed to appreciate Grass's originality.

The controversial reception of Die Blechtrommel almost immediately became part of the Flemish narrative about the novel; discussion of the novel goes hand in hand with references to its reception. This pattern continues when the novel is mentioned at the occasion of a review of its film adaptation. Here too, the reception becomes part of the review. The manner in which it was received in the us especially seems worth mentioning: "In several American states, the film was banned because of alleged paedophile scenes. This claim is of course ridiculous." 39 The reviewer here also uses spatial framing to distance himself from the American reception.

Another aspect of framing Die Blechtrommel by referring to its reception is to mention its commercial success. This also happened very early on in the reception. The first review said that "the book is in such great demand that it is almost out of stock." 40 Later reviews very often use the word 'success' and refer to large readerships and high sales figures, for instance: "more than four million copies of the book were sold;"41 or "Grass's most famous and best-selling book - hundreds of thousands of copies were also sold of the Dutch translation - is the epic novel Die Blechtrommel, published in 1959." ${ }^{\text {22 Commercial }}$ success legitimises discussion of the novel and increases its value in the readers' and reviewers' marketplace.

Mentioning the controversy surrounding the novel often implies mentioning the controversy surrounding Günter Grass as a public figure. This brings us to another and final important frame in the critical reception: the author.

\section{Frame 5: The Author}

This frame works both ways. On the one hand Die Blechtrommel is framed by reference to its author. This happens when it is for instance read as an ontological narrative in an autobiographical approach. Reviews that stressed the link

39 bva (2005). "In verschillende Amerikaanse staten werd de film intussen zelfs verboden omdat er pedofiele scènes zouden inzitten. Het vonnis slaat uiteraard nergens op."

$40 \quad$ Hartwijk (1959). "Het werk heeft zo'n aftrek, dat het bijna niet meer verkijgbaar is."

$41 \quad$ Van Nieuwenborgh (1999). "Van het boek zijn meer dan vier miljoen exemplaren verkocht." 
between the writer and the novel for instance tend to mention that Grass was born in Danzig, where the novel is situated. Autobiographical readings of Die Blechtrommel, however, are scarce. In interviews, the emphasis is of course placed on the author as a commentator on his own work; he is the authority on his novel. The novel is also described in the context of other topics related to Grass on such occasions: his political views, his childhood, his other books and so on. The frame for the book is Grass as a public figure then. After he talked about his past in the ss, some critics questioned the legitimacy of Die Blechtrommel. This is what Mona Baker would call assessment on the basis of characterological coherence: "If the decisions and actions associated with a character significantly change 'in strange ways' or contradict each other we inevitably question the credibility of the character and hence the narrative in question." ${ }^{43}$ No-one seems to truly doubt the credibility of Die Blechtrommel in the Flemish press however; all they do is - again - mention the controversy in Germany. They try to explain why Grass's confession was so shocking to Germans by referring to the moral stake of the novel. In his article "Why did Günter Grass keep silent? The credibility of Günter Grass is under discussion," Karel Verhoeven writes:

Günter Grass is not just an important German writer, not even just a Nobel Prize winner. He is the moral history teacher of the modern German state, the conscience of left-wing Germany. To remember and confront the past is the theme of his grand oeuvre. His debut novel Die Blechtrommel, by now a modern classic, condemned the schizophrenia of post-war Germany. The villainous hero Oskar Matzerath raked up nasty questions about guilt, complicity and responsibility. What is the difference between the Federal Republic and the Third Reich? Middleclass Germany thought it could hide away these questions in the flush of the Wirtschaftswunder. Grass found a new literary language to write German after Auschwitz. ${ }^{44}$

43 Baker (2006) 148.

44 Verhoeven (2006). "Günter Grass is niet zomaar een belangrijk Duits schrijver, zelfs niet zomaar een Nobelprijswinnaar. Hij is de morele geschiedenisleraar van de moderne Duitse natie, het geweten van links Duitsland. Herdenken en het verleden confronteren is het thema van zijn groots oeuvre. Zijn debuutroman Die Blechtrommel, intussen een moderne klassieker, laakte de schizofrenie van het naoorlogse Duitsland. De vileine held Oskar Matzerath rakelde akelige vragen op over schuld, medeplichtigheid, verantwoordelijkheid. Wat is het verschil tussen de Bondsrepubliek en het Derde Rijk? Het burgerlijke Duitsland dacht die vragen in de roes van het Wirtschaftwunder te kunnen 
So, for Flemish critics, Grass does not seem to lose his credibility or his characterological coherence following his confession. This is remarkable because Flanders too struggles with its war history. The wartime Flemish-nationalist collaboration with Germany keeps producing cultural narratives. This could be interpreted as a way of spatial framing, or of taking distance from Grass and Germany. It could indicate that what happens there is not the same as what happens here; that Grass is not one of 'us' but one of 'them'.

On the other hand, Grass is often framed by reference to Die Blechtrommel. Die Blechtrommel then becomes the frame through which Grass is identified and given a background and label. There are many examples of this technique, for instance, when Grass is called "the 71-year-old German author who is mostly known for his novel Die Blechtrommel." 45

\section{Coda}

The bottom line in reception studies is that a text has no meaning without the contribution of the reader. The reader, however, represents a broad concept. A distinction is often made between 'theoretical readers' and 'real readers. ${ }^{46}$ I have here focused on 'theoretical readers' and have left the 'real readers', who bring their own personal frames, out of this discussion. Critics are typically considered 'theoretical readers' because they are part of an institution and operate within the generic boundaries of literary criticism and the institutional boundaries of for instance a journal.

If one subscribes to the assumption that a text has no meaning without the reader's contribution, the term 'reception' seems inadequate since reading is then considered to be productive, and not passively receptive. I used Mona Baker's concept of 'frames' because it expresses that dynamic, productive dimension of reception. Once a narrative starts circulating, it interacts with other narratives; it is constantly retold by this interaction. In this paper, I mapped some of the frames that were used to 'retell' Die Blechtrommel in Flanders. Of course, more frames were activated when Die Blechtrommel entered the Flemish literary field than just the five I mentioned here.

An important aspect of narrative framing is that it works both ways. I did not just look at Die Blechtrommel through the prism of Flemish culture and

wegmoffelen. Grass vond een nieuwe literaire taal om na Auschwitz toch in het Duits te schrijven."

45 Pieters (1999). "de 71-jarige Duitse auteur, die vooral bekend is van Die Blechtrommel."

46 Brems /Ramos Pinto (2013). 
society, but also looked at Flanders through the prism of Die Blechtrommel: which narratives circulated at the time and which of them were activated by this book? That leads me to admit that this paper fell into the pitfalls of a conceptual narrative, since to study the reception of Die Blechtrommel in Flanders corresponds with the 'nationalistic' way our discipline usually operates, which is to study each language, each region as a more or less autonomous system. Many of the frames discussed here are not typically 'Flemish' but also have relevancy in other cultures. 'Flemish culture' is a frame, I, as a researcher, brought into this paper, just like the book in which this paper is published uses the frame of 'European culture' to study and narrate the reception of Die Blechtrommel in Europe.

\section{Bibliography}

Anon., "Fantasie en avontuur onder de kerstboom," in Het Nieuwsblad, December 18, 1998.

Baker, M., Translation and Conflict: A Narrative Account (New York, 2006).

Brems, E., “Engelse toestanden'. De vertaling en receptie van Charles Dickens in Vlaanderen in de negentiende eeuw," in N. Bemong, M. Kemperink, M. Mathijsen and T. Sintobin (eds.), Naties in een spanningsveld. Tegenstrijdige bewegingen in de identiteitsvorming in negentiende-eeuws Vlaanderen en Nederland, (Hilversum, 2010), 187-199.

Brems, E. \& S. Ramos Pinto, "Reception and Translation," in Y. Gambier \& L. van Doorslaer (eds.), Handbook of Translation Studies (Amsterdam, 2013), 142-147.

Bultinck, B., "Niets ontziend geroffel: Günter Grass. De blikken trommel," in De Morgen, April 8, 1999.

bva., "Die Blechtrommel," in De Standaard, January 15, 2005.

Decker, L. de., "9/11 in een roman: extreem ambitieus \& ongelooflijk gefaald," in Trends, May 26, 2005.

Derycke, E. “Blufboek. Günter Grass, De blikken trommel 1959," in De Standaard, July 14, 2006.

Durnez, E., "Late genoegdoening voor een kritische tijdgenoot," in De Tijd, October 2, 1999.

E.P., “Kanttekeningen bij Günter Grass's Die Blechtrommel," in De Periscoop 13 (1962), $1,11$.

Hartwijk, H., "Duitse Letteren. Nieuwe talenten," in De Nieuwe Gids, December 5/6, 1959. Joris, L., "Die Blechtrommel," in Knack, August 8, 2007.

kgv. "Wie 'Het verdriet' graag las, leest ook: (...) Günter Grass, De blikken trommel (1959)," in De Standaard, March 14, 2008. 
Meylaerts, R., “Identité 'propre’ ou identité 'empruntée’ des littératures mineures? Hétérolinguisme dans la traduction littéraire intra-belge," in Alternative Francophone 1 (2008), 1: 29-45.

Moonen, E., "De fabeltrommelaar: Bij de zeventigste verjaardag van Günter Grass," in De Morgen, October 16, 1997.

Nieuwenborgh, M. van, “Günter Grass krijgt eindelijk zijn Nobelprijs," in De Standaard, October 1, 1999.

Pearce, J., "Meulenhoff viert 5 ost ${ }^{\mathrm{e}}$ verjaardag van De blikken trom van Günter Grass met nieuwe vertaling," in De Morgen, July 22, 2009.

Pesch, L., "Die Blechtrommel van Günter Grass. Vraag of satan een goed kunstenaar is," in West-Vlaanderen 10 (1961), 344-46.

Pieters, R., "Nobelprijswinnaar zat bij de tandarts," in De Morgen, October 1, 1999.

Theunissen, J., "Niet meer groeien," in De Standaard, June 19, 2009.

Verhoeven, K., “Waarom zweeg Günter Grass?” in De Standaard, August 16, 2006.

Verkein, Lea. "Die Blechtrommel. De eerste roman van Günter Grass," in De Vlaamse Gids 44 (1960), 651-52.

Verplancke, M., "Extreem verbonden \& ongelooflijk eenzaam," in De Morgen, May 25, 2005 .

Wachter, M. De, “Grass, Günter. Die Blechtrommel," in Streven 14 (1961), 507. 